\title{
内部階段におけるデザイン構成 の心理評価分析
}

\section{PSYCHOLOGY EVALUATION ANALYSIS OF THE DESIGN CONSTITUTION IN INSIDE STAIRS}

\author{
積田 洋—— 1 \\ 中山誠健 —— 3 \\ 須賀 睦 — $* 2$ \\ キーワード : \\ 階段, デザイン, 構成要素, 心理評価, 数理的分析
}

Keywords:

Stairs, Design, Constituent elements, Psychological assessment, Mathematical analysis

\section{1. 研究意義 - 目的 - 方法}

階段は、建築にとって人々を上下に移動させる機能的かつ基本的 な要素でありながら、建築空間を演出し、訪れる人々を魅了する要 素として重要である。また、ルーブル美術館やオルタ邸、日生劇場 などに見られる階段の空間は、建築空間の中でその建築を特徵づけ る象徵的な空間として用いられている。それらの階段デザインを構 成する要素は手摺・手摺子 (若しくは壁)、蹴上げ、踏み面及び幅の 操作という、少数の基本的構成要素で成立している ${ }^{\text {注 } 1)}$ にも関わらず、 それらの形態や素材の組み合わせの違いにより、デザインも多様に なり、全く異なる印象や䨌囲気を演出している。それゆえ不特定多 数の利用者に与える影響を設計者が推測するのは容易ではない。例 えば、手摺がどの程度洗練された印象に影響するかなど階段デザイ ンの評価の視点が客観的に分かれば、階段及びその周辺空間のデザ インを設計段階で決定する指標として有効な資料となる。

階段に関する既往の研究としては、安全性や利便性、機能面に着 目した研究や、視認性や注視行動など人間工学的な側面から空間の 印象を明か寸研究 ${ }^{1)}$ は見られるが、階段のデザインに着目し、その 印象や䨌囲気を客観的に評価したものは見られず、建築家や設計者 の経験に基づく主観に頼っている。一方、筆者らが既に発表した研 究では、実際の空間において実験を行い、階段全体を捉える見上げ たシーンの印象や移動に伴い床や壁から見え隠れ寸る特徴的なシー ンが階段の魅力に強く関係することなど、階段及びその周辺空間の 空間構成がその空間体験者にどのような印象を与えるかなど研究成 果を得ている ${ }^{2)}$ 。また、階段の構成要素の変化が印象に与える影響 についてもコンピュータグラフィックス（以下 CG と訳）画像を用い

\section{Hiroshi TSUMITA $-* 1 \quad$ Mutsumi SUKA $-* 2$ \\ Yoshitake NAKAYAMA — $* 3$}

In this research, it was aimed at clarifying the influence that the difference of the basic component of stairs gave the evaluation of the stairs design objectively. The basic component of stairs was a plan, width, a handrail including the material, the constitution of the tread, a placement condition.

Various stairs of 74 objects were selected. It performed an evaluation experiment by the photograph image after having paid off the basic component of stairs 11 to an items.

It showed the tendency to evaluation and relations of the constitution with a multivariate analysis quantitatively, and showed an effective document at a design stage.
た画像評価実験により、階段デザインの評価構造 14 因子軸を客観的 に明らかにした ${ }^{3)}$ 。しかし、CG 画像による素材感の表現が実空間に 対して差異が見られた点や、螺旋や曲線形状の階段が無い限られた 実験サンプルであった点など、階段を構成する様々な要素が組み合 わされたパターンにおける階段のデザインと評価の関係については 言及していない。

そこで本研究は、これまでの研究成果を踏まえた上で、手摺・手 摺子や踏み面の素材感を含む、より多様なデザインの階段を対象と し、階段の基本的構成要素である平面形態や幅、素材の違いを含む 手摺、踏み面の構成、配置条件が階段デザインの評価に与える影響 を客観的に明らかにすることを目的とする。

具体的には、(1)国内外の専門書や建築雑誌、デザイン雑誌 ${ }^{4)}$ から 多様な階段の形態やプロポーション、構成要素が把握出来る、階段 を見上げた写真を選定し、(2)構成要素の定義・抽出・定量化を行う。 次に(3)写真画像を用いた心理評価実験を行い、その結果と構成要素 との関係を分析・検討した上で、(4)数量化理論 I 類分析を用いるこ とで、階段のデザインと心理的評価の関係を客観的に示し、設計段 階で有効な資料の提示を行う。

\section{2. 階段の選定及び基本的要素の抽出}

階段の構成が把握できる建築空間における階段事例を収集し、そ の中から階段の形態やプロポーション、構成要素、見上げの状態を 把握出来ないものを除いた 74 事例（ST1 - ST74）を研究調查対象と して選定した。これらの階段の形態の構成を細かく分類した上で、 既報で得られた階段の印象として重要な見上げの印象 ${ }^{2)}$ に影響寸る

\footnotetext{
1 東京電機大学未来科学部建築学科 教授 - 博士 (工学)

(下 101-8457 東京都千代田区神田錦町 2-2)

(株)大建情報システム

東京電機大学未来科学部建築学科 非常勤講師・博士（工学）

$*^{*}$ Prof., Dept. of Architecture School of Science \& Technology for Future TDU Dr.
Eng.
$*^{*}$ Daiken Information System INC.
Lecturer of Architecture School of Science and Technology for Future TDU Dr.
Eng.
} 
と考えられる構成要素を選定した。平面形状、階段幅、踊り場（数）、 蹴込み板の有無、ささらの形態、手摺・手摺子の形態、空間、配置 に加え、CG 画像では評価できなかった手摺・手摺子の素材、踏み面 の素材、階段全体の素材数の計 11 アイテムを設定し、それぞれ 2 ～5、 計 38 カテゴリを設定した。74 事例の階段 ${ }^{\text {注 }}$ についてそれらのアイ テムカテゴリの該当の有無を捉えた（表 1, 図 1)。

\section{3. 心理評価実験}

\section{3-1. 実験方法}

写真画像を対象とした印象を客観的に捉えるために 7 段階評定尺 度の SD 法による心理評価実験を行った。評価軸は、既報 ${ }^{3)}$ の研究 で得られた空間全体評価ならびに階段デザイン評価について収集し た形容詞句対を、因子分析を行い階段の心理評価構造として抽出し た 14 尺度とした。実験は、80 インチのスクリーンにプロジェクター で投影した画像を約 $3 \mathrm{~m}$ 離れた位置を視点として被験者に印象を評価 させた。なお、被験者は階段デザインや具体的な構成を評価可能と 考えられる建築学科の学生 27 名とした。

\section{3-2. 心理量分析}

心理評価実験の結果を集計し、評価傾向を検討した上で、評価值 の平均值（以下、心理量と表記する）をもとに分析を行った。以下、 特徵的な結果を述べる。

「躍動的な感じ」は、心理量が 2.9 から 5.8 に分布し、平面形状や 手摺子が曲線的なデザインで蹴込み板が無い ST 51 が最も高く評価さ れた。また、心理量が 4.0 以上の対象に着目寸ると、螺旋状など曲 線的なデザインの階段が多く見られたほか、手摺子の素材がガラス のものも 14 件と多く見られた。一方、曲線的なデザインでも 4.0 以 下の階段はST57（3.7）やST36（3.3）で、共通する特徴として壁で 階段全体の長さが捉えられない、もしくは短かい階段であった。最 も滞った感じと評価されたのは折り返しで手摺子が縦栈のST32 で あった。以上の傾向から、平面形状の曲線や直線、手摺の素材の違 いが躍動感評価のばらつきに影響していると考えられる（図 2-1)。

「軽快感のある感じ」は、1.8 から 6.0 に分布し、折れ曲りで吹抜 け空間の中央に配置された ST4 (5.9) やST7 (5.6) などが高い。4.0 以 上の 32 対象の共通点は、階段下が壁ではなく抜けている点と云える。 また、 4.0 以上の階段は「現代的な感じ」の評価でも 4.0 以上であり、 現代的な階段＝軽快なデザイン、古典的な階段＝重厚なデザインと いう関係が読み取れる。なお、最も低い ST32 は「現代的な感じ」で も最も低く、「古典的な感じ」と評価された。そのほか、4.0 以下は 蹴込み板のないST5 (3.4) やST29 (2.6) が見られた（図 2-2）。

「シンボリック性のある感じ」は、 2.9 から 6.3 に分布し、4.0 以 上は 60 対象（80\%以上）と多く、階段の象徵性が確認された。左右 対称の折れ曲がり形状のST15 が最も高く、螺旋状の階段も全て 4.0 以上となった。また、4.0 以下の無個性的と評価された階段は、平面 形状が直線のものが 11 件と多い (図 2-3)。

「流動的な感じ」は 2.9 から 6.1 に分布し、螺旋状で手摺子がガラ ス材の ST18 とST33 が 6.0 以上の高い評価を得た。また、上位 12 対 象の平面形状は螺旋もしくは曲線で、4.0 以下は平面形状が全て直線 であることから、流動性には平面形態の影響が大きいと考えられる。
表 1 事例数と物理的構成カテゴリ

\begin{tabular}{|c|c|c|c|c|c|c|c|c|c|c|c|c|c|}
\hline \multirow[b]{2}{*}{$\begin{array}{l}\text { 構成要素 } \\
\text { テイデム) } \\
\text { テゴリ) }\end{array}$} & \multicolumn{5}{|c|}{ 平面形状 } & \multicolumn{3}{|c|}{ 階段幅 } & \multicolumn{3}{|c|}{ 踊り場(数) } & \multicolumn{2}{|c|}{ 蹴込み板 } \\
\hline & $\begin{array}{l}\text { 直 } \\
\text { 線 }\end{array}$ & \begin{tabular}{l|} 
曲 \\
線
\end{tabular} & \begin{tabular}{|l|} 
螺 \\
旋 \\
\end{tabular} & $\begin{array}{c}\text { 折 } \\
\text { れ } \\
\text { 曲 } \\
\text { り }\end{array}$ & $\begin{array}{l}\text { 折 } \\
y \\
\text { 返 } \\
\text { 乙 }\end{array}$ & \begin{tabular}{c|} 
狭 \\
W \\
$1.6 \mathrm{~m}$ \\
以下 \\
\end{tabular} & \begin{tabular}{c|} 
中 \\
間 \\
\end{tabular} & $\begin{array}{l}\text { 広 } \\
\text { W } \\
3.0 \mathrm{~m} \\
\text { 以上 } \\
\end{array}$ & 無 & \begin{tabular}{|c|} 
\\
吕 \\
所
\end{tabular} & \begin{tabular}{|l} 
複 \\
数 \\
芳 \\
所
\end{tabular} & $\begin{array}{l}\text { 有 } \\
\text { り }\end{array}$ & 無 \\
\hline 事例数 & 32 & 9 & 6 & 18 & 9 & 19 & 35 & 20 & 24 & 40 & 10 & 55 & 19 \\
\hline アイテム(\%) & 43.2 & 12.2 & 8.1 & 24.3 & 12.2 & 25.7 & 47.3 & 27 & 32.4 & 54.1 & 13.5 & 74.3 & 25.7 \\
\hline $\begin{array}{l}\text { 構成要素 } \\
\text { テイデム } \\
\text { テゴリ) }\end{array}$ & $\begin{array}{l}\text { ガ } \\
\text { 亏 } \\
\text { 材 } \\
\text { 材 }\end{array}$ & $\begin{array}{l}\text { 踏 } \\
\text { 金 } \\
\text { 属 } \\
\text { 材 }\end{array}$ & \begin{tabular}{l|}
\multicolumn{2}{c|}{ 面素 } \\
\multicolumn{1}{|c}{ 木 } \\
材
\end{tabular} & \begin{tabular}{|c|} 
梦材 \\
石 \\
材
\end{tabular} & $\begin{array}{l}\text { ク } \\
\text { 口 } \\
\text { ス } \\
\text { 材 }\end{array}$ & $\begin{array}{c}\text { 段 } \\
\text { 横 } \\
\text { 段 } \\
\text { 状 }\end{array}$ & \begin{tabular}{l|}
\multicolumn{2}{c|}{ ささ } \\
段 \\
横 \\
$\dot{⿱}$ \\
斜 \\
状 \\
\end{tabular} & \begin{tabular}{l|}
5 \\
段 \\
\end{tabular} & $\begin{array}{l}\text { 壁 } \\
\text { 面 }\end{array}$ & 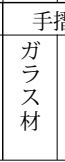 & \begin{tabular}{|c|} 
習・手振 \\
金 \\
属 \\
材
\end{tabular} & $\begin{array}{l}\text { 習子素极 } \\
\begin{array}{c}\text { 木 } \\
\text { 材 }\end{array}\end{array}$ & $\begin{array}{l}\text { 材 } \\
\text { 石 } \\
\text { 材 }\end{array}$ \\
\hline 事例数 & 2 & 13 & 19 & 32 & 8 & 9 & 28 & 17 & 20 & 18 & 37 & 7 & 12 \\
\hline アイテム(\%) & 2.7 & 17.6 & \begin{tabular}{|l|}
25.7 \\
\end{tabular} & 43.2 & 10.8 & 12.2 & 37.8 & 23 & 27 & 24.3 & 50 & 9.46 & 16.2 \\
\hline $\begin{array}{l}\text { 構成要素 } \\
\text { テイデム } \\
\text { テゴリ) }\end{array}$ & $\begin{array}{l}\text { 縦 } \\
\text { 栈 }\end{array}$ & 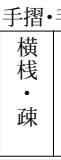 & \begin{tabular}{c|} 
手摺子 \\
横 \\
栈 \\
$\dot{⿱}$ \\
密
\end{tabular} & \begin{tabular}{|} 
子形態 \\
壁 \\
\end{tabular} & $\begin{array}{l}\text { 装 } \\
\text { 飾 } \\
\text { 的 }\end{array}$ & \begin{tabular}{l|}
\multicolumn{2}{|c|}{ 素 } \\
単 \\
数
\end{tabular} & 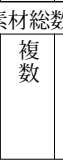 & 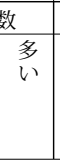 & \begin{tabular}{l|}
\multicolumn{2}{c|}{ 空侄 } \\
吹 \\
抜 \\
け \\
有 \\
り
\end{tabular} & \begin{tabular}{|l|} 
間 \\
吹 \\
抜 \\
け \\
無 \\
己
\end{tabular} & \begin{tabular}{l|}
\multicolumn{2}{|c|}{ 配 } \\
中 \\
央
\end{tabular} & \begin{tabular}{|c|} 
置 \\
譬 \\
⿹ \\
\end{tabular} & \\
\hline 事例数 & 15 & 14 & 6 & 33 & 6 & 15 & 37 & 22 & 59 & 15 & 29 & 45 & \\
\hline アイテム(\%) & 20.3 & 18.9 & 8.11 & 44.6 & 8.11 & 20.3 & 50 & 29.7 & 79.7 & 20.3 & 39.2 & 60.8 & \\
\hline & 型 & & & & & 返し & & & & & 斤れ曲り & & \\
\hline
\end{tabular}

図 1 階段のデザイン構成要素

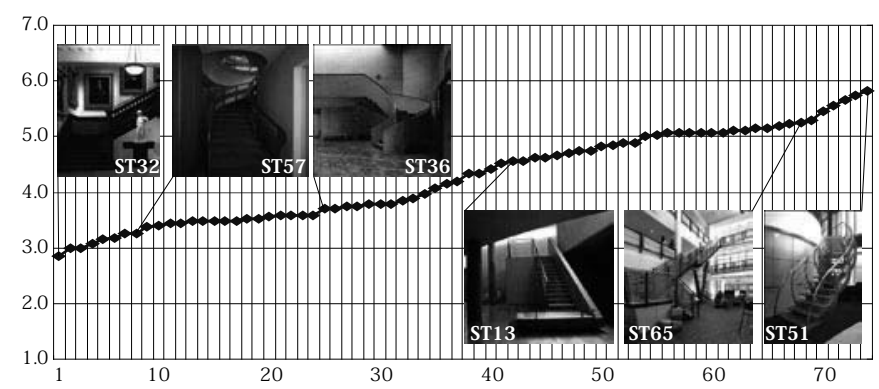

図 2-1 心理量降順《滞った感じ (1.0)- 躍動的な感じ (7.0)》

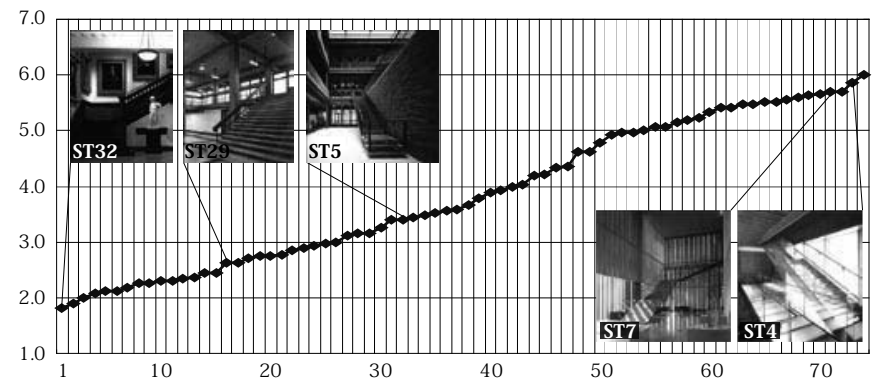

図 2-2 心理量降順《重厚感のある感じ (1.0)-軽快感のある感じ (7.0)》

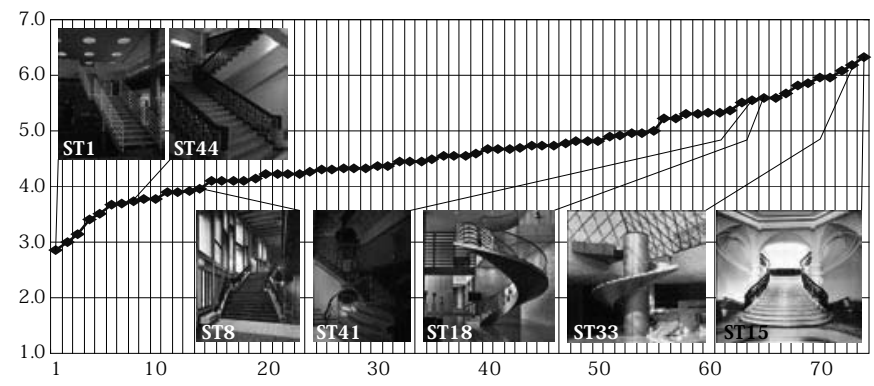

図 2-3 心理量降順《無個性的な感じ (1.0) シンボリック性のある感じ (7.0)》 


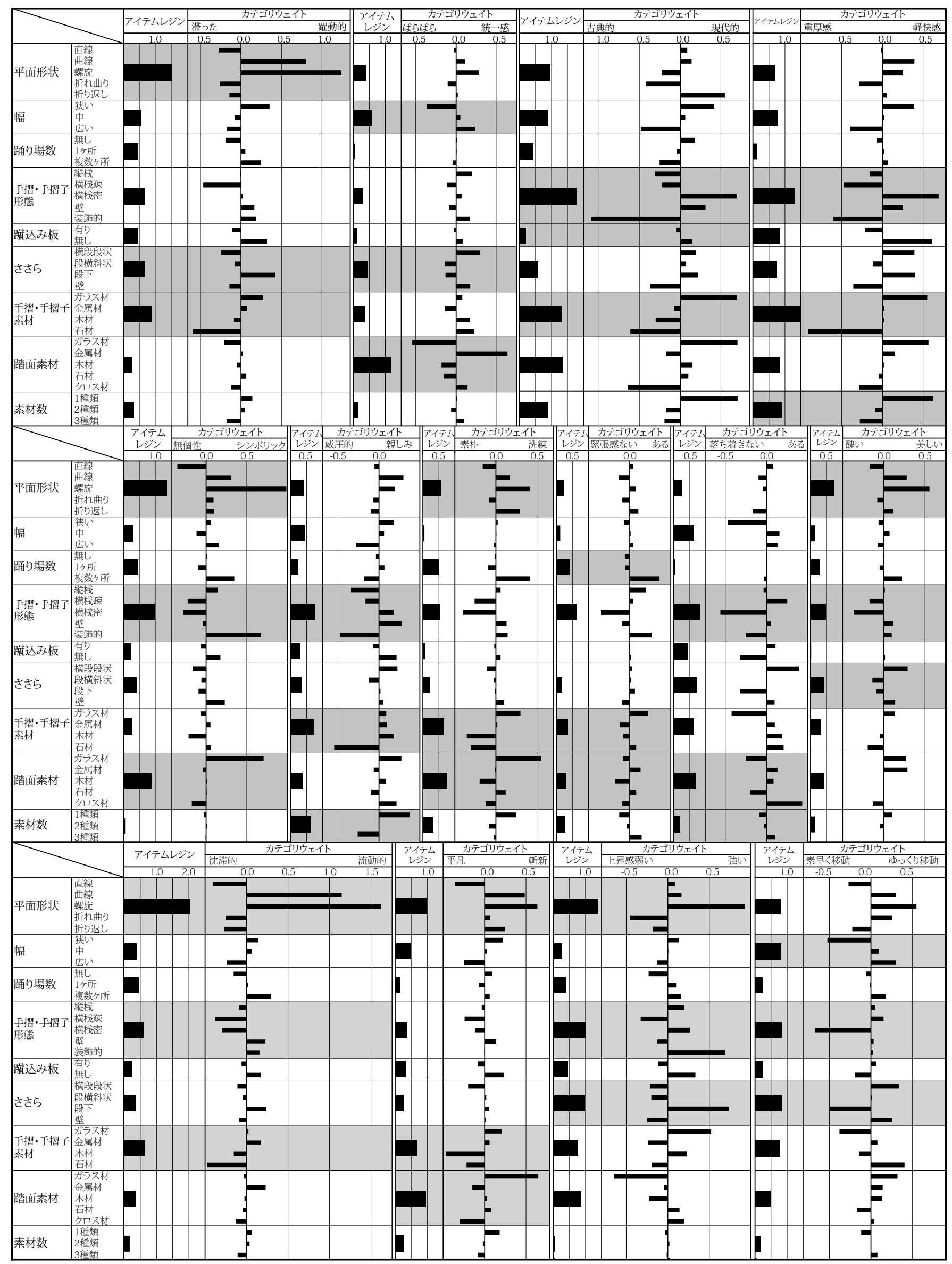

図 3 構成と評価の関係（数量化理論 I 類分析結果）

* $\square$ はアイテムレンジ (目的変数である心理量に対する説明変数項目の值) の上位 3 位 カテゴリウェイトは説明変数項目に対する分類の值 


\section{4. 構成要素と心理評価の相関分析}

一つの要素のみならず複数の構成要素が、階段デザインの印象や 䨌囲気に影響を与えることから、それらの相互の関係をその強弱も 含めて具体的かつ定量的に捉えるために、多変量解析（数量化理論 I 類分析）を用いた分析を行った（図 3)。その結果、階段のデザイ ンを評価する際に最も影響する要素は手摺・手摺子の形態や素材で、 あらゆる評価に影響することが示されたことから、その階段を印象 付ける構成要素として手摺・手摺子が最も重要であると云える。次 いで影響する要素は平面形状で、踓動性、シンボリック性、美しさ、 流動性、斬新性、上昇性、の 6 項目について最も影響する要素で、 また洗練性にも影響する。踏面素材の影響も大きく、統一感、洗練性、 について最も影響し、現在的、シンボリック性、落ち着き、斬新さ にも影響する。一方、蹴込み板の有無が階段デザインや雰囲気の評 価に与える影響は極めて少ないことが示された。

\section{5. まとめ}

異なった多数の階段の写真による心理評価と数量化理論 I 類分析 を通して、従来漠然と捉えられてきた階段のデザインと心理的評価 の関係を客観的かつ具体的に明らかにした。階段の象徵性が確認さ れ、以下に階段デザインと心理評価の関係を示す。

(1)躍動感を感じさせる階段は、平面形状の操作が有効で、螺旋状 にすると効果的であるほか、幅が概ね $1.6 \mathrm{~m}$ 以下で踊り場を必要とす る比較的長いデザインである。

(2)金属素材で構成されたデザインは統一感を得易いが、ガラスで は逆の印象となる。特に踏み面がこれらの素材の場合にその傾向が 強くなる。

(3)重厚感を感じさせる古典的なデザインは、手摺子の形態や素材 の操作が有効で、石材や装飾的な形態が適し、現代的なデザインは ガラスもしくは素材を統一するとその傾向が強まる。

(4)軽快な階段デザインを演出するには手摺を操作することが効果 的で、手摺子の形態を横栈にしたり、素材をガラスにすると有効で ある。一方、石材では重厚感が得られる。

(5)より象徵的な印象のデザインは、螺旋状への平面形状の操作が 最も有効である。また、手摺をST41 の様な有機的な装飾やST44の 様な幾何学的なものも有効である。

(6)親しみ易い階段は、素材を統一したり幅を概ね $3 \mathrm{~m}$ 以下にすると 得られる傾向にある。

(7)手摺子の横栈は比較的素朴な印象を与えるため、洗練された印 象にするには、平面形状を螺旋や折れ曲りにしたり踏み面素材をガ ラスにすることが有効である。

8踊り場数が 2 つ以上、つまりレベル差が大きく長い階段は緊張 感を与える。それを緩和するには手摺子の形態や素材の操作が有効 で、横栈の手摺もしくは金属や木材を用いることで効果が得られる。

(9)落ち着いた印象は、踏み面を布にしたり、階段幅を 1.6 - $3 \mathrm{~m}$ に することで演出される。

(10)螺旋状の階段は美しい印象を与え易いが、そのほかの平面形状 でも段状のささらが横に配された階段などの評価が高い傾向が見ら れた。
(11)流動的なデザインには曲線の平面形状が効果的である。

(12)斬新性は、平面形態を螺旋や曲線にするほか、踏み面の素材を ガラスにすることで得られる。また、直線的な平面形態であっても 踏み面や手摺子の素材にガラスを用いたり、蹴込み板を抜くと効果 が得易い。

13)上昇感の強い印象を与えるには、平面形状を螺旋状にするほか、 ST15 の様な装飾的な手摺のデザインや踏み面が水平性に連続する様 に、ささらを段下に配置することで得られる。また、踏み面の素材 がガラスや平面形状が折り返しの階段は、上昇感よりも美しさや斬 新性、洗練性を高く評価される。

(14)階段の移動をゆっくり楽しみたくなるデザインは、階段の幅が 概ね $1.6 \mathrm{~m}$ 以下では得られにくく、それ以上で評価が高くなる。また、 ささらの操作も有効で、横に配したり壁で覆うことでも効果が得ら れる。

以上、その評価の視点を定量的に記述出来たことは、今後、階段 を計画する際の有用な資料となると考える。

注

注 1）槙文彦のディテール 空間の表徴 - 階段, 彰国社, 1999, p. 8 左段 15 行目 注 2) 代表的なものについては、図中に写真を掲載

参考文献

1) - 柳瀬亮太 , 鈴木英水：踏面・蹴上寸法と階段歩行時の印象評価との関係, 日本建築学会計画系論文集 第 637 号, pp. 585-591, 2009. 3

- 永田久雄： 主観的評価に基づく踏面・蹴上寸法の検討 階段の安全性から みた踏面・蹴上げ寸法の評価に関する研究 その 3 , 日本建築学会計画系論 文報告集 第 456 号, pp. 145-152, 1994.2

・布田健, 直井英雄ほか：視認性に影響を及ぼす各種要因に関する研究事故 防止の観点より見た階段各段の視認性に関する研究（1），日本建築学会計 画系論文報告集 第 450 号, pp. 75-82, 1993.8

・高井智代 , 松本直司ほか：階段昇降時の視覚的識別性 - 公共空間におけ る視覚障害者の歩行安全性に関する研究 その 3 -, 日本建築学会計画系論文 集 , 第 589 号, pp. 55-62, 2005. 3

-鈴木利友 , 岡崎甚幸 : 地下鉄駅舎出入口における階段歩行時の注視行動， 日本建築学会計画系論文集, 第 558 号, pp. 151-158, 2002.8

2) 中山誠健 ・積田洋 ・浦部智義 : 階段移動に伴う印象の変化と空間構成に関寸 る研究, 日本建築学会計画系論文集 第 638 号, pp. 831-837, 2009.4

3) 中山誠健, 積田洋, 浦部智義, 元田草太, 須賀睦 : 階段空間における基本的構成要 素が及ぼすデザインの評価の研究, 日本建築学会計画系論文集 第 654 号, pp. 1883-1888, 2010. 8

4)・彰国社 : ディテール 176, 彰国社, 2008

・INAX : 階段物語り, INAX ギャラリー, 1993

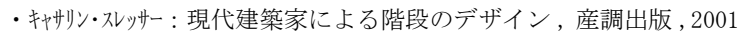

- Pilar Chueca : the art of STAIRCASES, PAGE ONE, 2006

- Aisha Hasanovic : UPSTAIRS DOWNSTAIRS, images Publishing, 2006

- Haike Falkenberg : staircases, teNeues, 2002

- 美術出版 : 建築家 前川國男の仕事, 美術出版社, 2006

・日経アーキテクチュア : [NA 選書 ] 手すり大全, 日経 BP 社, 2008

[2011 年 2 月 18 日原稿受理 2011 年 7 月 1 日採用決定］ 